\title{
Socio-Ecological Drivers of Land Use Change and Wetland Conversion in Kilombero Valley Floodoplain, Tanzania
}

\author{
Nangware Kajia Msofe ${ }^{1,2}$ \\ ${ }^{1}$ School of Environment, Northeast Normal University, Changchun, China \\ ${ }^{2}$ Department of Environmental Studies, the Open University of Tanzania, Dar es Salaam, Tanzania
}

\section{Email address:}

mof742@nenu.edu.cn

\section{To cite this article:}

Nangware Kajia Msofe. Socio-Ecological Drivers of Land Use Change and Wetland Conversion in Kilombero Valley Floodoplain, Tanzania. American Journal of Environmental and Resource Economics. Vol. 4, No. 1, 2019, pp. 1-11. doi: 10.11648/j.ajere.20190401.11

Received: November 13, 2018; Accepted: December 7, 2018; Published: January 24, 2019

\begin{abstract}
Connections between social drivers (human activities) and ecological drivers (natural events) are currently considered as the key factors affecting land use change in tropical wetland ecosystem. However, the complexity interaction of these socio-ecological drivers is often poorly understood. This paper examined the interaction of these two systems in the Kilombero valley floodplain. Kilombero valley floodplain is one of the largest tropical wetland in Africa offering a wide spectrum of habitats for plant and animal species sustaining several ecosystem services and ecological functions, which has been under threat of wetland loss and degradation. The study used the documentary review approach to investigate the interaction of socio and ecological systems in the study area. The study revealed that population growth, market growth and price incentive for cash crops and timber products coupled with improved infrastructures, policy and institutional framework are the social drivers, while flat terrain characteristics, heavy black alluvial soils coupled with high water holding capacity, increased temperature and rainfall variability accompanied with prolonged dry spells are the ecological drivers of land use change and wetland conversion in the study area. However, there are relationships among these drivers, as they act simultaneously as well as differently to influence land use changes in the study area. The study recommended that socioecological interactions and the needs of local communities whose livelihood is highly dependent on wetland resources must be central to the development of wetland policies and wetland management approaches.
\end{abstract}

Keywords: Wetland Conversion, Land Use Change, Socio-Ecological Drivers, Kilombero Valley Floodplain, Population Growth, Ecosystem Services, Wetland Management, Livelihood

\section{Introduction}

Wetlands are areas that are inundated or saturated by surface or ground water at a frequency and duration sufficient to support, a prevalence of vegetation (hydrophytes) typically adapted for life in saturated soil conditions (hydric) [1]. They may incorporate riparian and coastal zones adjacent to the wetlands and islands or other bodies of marine water deeper than six meters at low tide lying within the wetlands [1]. Wetland occupies about $6 \%$ of the earth's land surface [2]. In Tanzania, its potentials are quite significant and it is estimated to occupy $10 \%$ of the Tanzania's land surface; extremely rich ranging from coastal marine to freshwater wetlands [3, 4]. There are four sites in Tanzania which are designated as wetland of International importance with surface size in parenthesis namely Malagarasi-Muyovozi (3
250000 ha), Lake Natron Basin (224 781 ha), Kilombero Valley Floodplain (KVFP) (796 735 ha) and Rufiji-Mafia Kilwa (596 906 ha) [5].

Wetlands provides opportunities for the livelihoods activities through crop production, grazing pastures, fishing, hunting, medicinal plants, water and other human support to local communities living around them [6, 7]. Moreover, it provides valuable ecosystem services such as sediments and nutrients retention, water supply, flood control, carbon storage and recreation to human. Such services have both global importance and local values [5]. Despite its importance they are among one of the most endangered and fastest declining ecosystems due to complex interactions of the socio and ecological drivers that leads to wetland conversion and degradation [8,9]. Among social drivers include increase in population that increased the demand for 
food supply and improved income has resulted to overexploitation of wetland resources and inappropriate agricultural practices that led to wetland conversion and degradation[10]. The conflict and unclear land tenure coupled with a desire for higher income, incentive in commodity prices have driven the community to transform from traditional to extensive cropping systems and expansion of cultivated land into the protected wetland [10]. These interactions and feedback relationships between the livelihood activities and the threats from change in land use and land cover of wetland ecosystems have to be studied.

Ecological drivers that accelerate tropical wetland conversion and degradation include geologic setting, climate and its variation, patterns of primary productivity, hydrological processes, and other bio-geophysical factors [11-13]. The processes of wetland conversion and degradation associated with land use change undermine the capacity of wetlands to provide both ecosystem services and livelihood opportunities to the communities that depend solely on them [14]. Kilombero valley flood plain is one of the largest tropical wetlands in Africa offering a wide spectrum of habitats for plant and animal species, sustaining several ecosystem services and ecological functions $[15,16]$. These floodplain wetlands are endowed with a productive natural resource base, fertile land, reliable water availability and extensive pastures, making it the major focal area for the Tanzanian government particularly in its bid to transform the farming system and eradicate poverty in the country [17]. Despite of their vital importance these floodplain wetlands are experiencing land use change and wetland conversion.

Various studies have revealed that, wetland conversion and degradation occurs at extremely high rates in the globe [18]. In US for instance, $53 \%$ of wetlands were lost between the 1780 s and 1980s, with Ohio and California losing 90\% and $91 \%$ respectively [2]. Estimated wetland loss in different parts of Canada ranged between $65 \%$ and $80 \%$ [19]. In parts of Europe, Australia and New Zealand more than $50 \%$ of specific types of wetlands were destroyed during the twentieth century [8, 20]. In Sumatra and Kalimantan, Indonesia, it was estimated that during the twentieth century less than $4 \%$ of peat land, comprising undisturbed pristine peat swamp forests, remained and while $37 \%$ displayed varying degrees of degradation [21]. Significant wetlands conversion has also been observed in Africa where by $2 \%$ of the wetland area had been drained for intensive agriculture [4].

Tanzania like any other African countries, face the problem of land use change and wetland conversion. For example, Kilombero valley floodplain has been more vulnerable due to agricultural expansion and intensification, expansion of grazing land and deforestation associated with various socio-ecological drivers. This study therefore reviewed various studies on social drivers (human activities) and ecological drivers (natural events) that are responsible for land use change and wetland conversion in Kilombero valley floodplain (KVFP), the interactions among socioecological drivers, based on which recommendation could be proposed for the biodiversity conservation.

\section{Objective of the Study}

The objective of this study was to examine the interaction of social drivers (human activities) and ecological drivers (natural events) that led to land use change and wetland conversion in Kilombero valley floodplain (KVFP).

\section{Literature Review}

\subsection{Definition of Operational Terms}

\subsubsection{Wetland}

The concept of wetland has many definitions, but there are three characteristic features that play a part in all of the definitions: hydrology, soils, and vegetation. Wetland is defined as area of land where saturation with water is the dominant factor determining the nature of soil development and the types of plant and animal communities living in the soil and on its surface [22]. Also can be defined as ecosystems whose formation has been dominated by water, and whose processes and characteristics are largely controlled by water [1]. Wetlands constitute a wide range of in inland, marine and coastal habitants which share a number of common features. Ramsar Convention on Wetlands (signed and named after the Iranian city of Ramsar where the first conference was held in 1971) defines wetland as areas of marsh, fen, peat land or water, whether natural or artificial, permanent or temporary, with water that is static or flowing, fresh, brackish or salt, including areas of marine water with the depth of which at low tide does not exceed six metres [5].

\subsubsection{Land Use Change}

Land use change refers to changes in an existing land use to another land use type or a change in the intensity of an existing land use [12]. For example, expansion of agricultural land frontier by clearing new land (extensification) or the application of more agricultural inputs to increase output per unit of land (intensification). Land use/cover changes can also be referred to urbanization, conversion of natural habitat to pasture land and decrease of forest cover [6].

\subsection{Wetland Functions and Values}

The value of a wetland is an estimate of the importance or worth of one or more of wetland functions to society [23]. The determination of the value of individual wetland is difficult as they differ widely and do not all perform the same functions or perform functions equally well, thus decision makers should understand the impacts on wetland functions that can diminish the values of wetlands. It is known that there are two major categorical functions of the wetlands namely ecosystem functions and human use both of which have economic values [24]. The ecosystem functions of wetlands include ground water recharge and discharge, shoreline stabilization and reduction of erosion, sediment trapping, nutrient retention, support for food chains, and 
habitat for wildlife, recreation, natural heritage values, macro and microclimate stabilization [25]. The additional ecosystem functions of the wetland include flood prevention, stabilization of ecological communities, carbon storage, water purification and water transport that ensure year round flow of water for human consumption, irrigation and hydropower generation [19]. The wetland function to human include provision of people's livelihoods through crop production, grazing pastures, tourism, fishing and hunting to local communities living around the wetland and this contributes to food security and income [5]. Poor rural households, mostly women, rely on wetlands for additional income to their families. Additionally, wetlands contribute extensively to the efforts aimed at poverty reduction and food self-sufficiency in most parts of the world [8, 26].

\subsection{Major Socio and Ecological Drivers for Land Use Change and Wetland Conversion}

Land use change and wetland conversion are the result of interaction of social and ecological processes on a landscape, driven by complex cause or driving forces. The socioecological systems are defined as an ecological system complex linked with and affected by one or more social systems [27]. The ecological system comprises of geologic setting, climate and its variation, patterns of primary productivity, hydrological processes, and other bio geophysical factors [11]. The social system acts synergistically rather than by single-factor causation, with more than one-third of the cases being driven by the full interplay of economic, policy and institutional framework, technological, cultural, and demographic factors [27].

Economic factors define a range of market variables such as input and output prices, market access, subsidies and credit access that have direct impact on land manager's decisions in relation to the land use [13]. The high output market prices for agricultural products for example compel farmers to increase productivity through allocation of more resources such as labour, fertilizers and agro chemicals on limited land to maximize output hence agricultural intensification [28]. On the other side, increase in agricultural inputs prices makes farming less profitable thus farmers reduces the land area devoted to agricultural production or substitute land in the way that leads to forest clearing hence agriculture expansion [29]. However, access to market and increased market price for the agriculture and forest products stimulates the deforestation and agricultural expansion in most part of the developing countries that depends solely on the natural resources.

Institutional factors consist of institutional framework and policies related to land use and management. Land use involves considerations of human decisions with particularly crucial roles played by government policies and programmes in the management of natural resources. Policies for agriculture, forestry, trade and investment, and other landbased activities, land tenure arrangements and policy failures are considered as institutional factor for land use change and wetland conversion [11]. For instance, the land tenure uncertainty has accelerated community land clearing using fire, accelerating massive deforestation in tropical peat lands of Central Kalimantan, Indonesia [30]. Also, the conflict and unclear land tenure has driven the community to convert and reclaim large parts of the wetland into rice farms in Ha Tien Plain, Mekong Delta, Vietnam [10].

Furthermore, technological advancement has been a dominant driver behind changes in land use. In agriculture for example, technology has direct effects on farmer's behaviour and decisions pertaining to resources utilization. Technologies contribute to agricultural expansion and intensification. Agriculture intensification involves the access to high yield-increasing technologies such as the use of fertilizers, pesticides and improved seeds that provide opportunities to increase agricultural production on the same amount of land [28]. Agricultural expansion involves massive clearance of the land for agriculture and is assisted with the use of technologically advance machines such as tractors and power tillers. In forest, extensive deforestation is attributed to the use of advanced machines such as saw machines for logging. Likewise, poor technological applications in the wood sector may lead to wasteful logging practices, which results into deforestation [11].

Cultural factor is associated with attitudes of public concern towards environment. Culture consists of material components and artifacts, such as religious beliefs, knowledge, arts, objects, tools, machinery and infrastructure that also shapes the behaviour of individual toward environment which may influence land use change [11]. For instance, in some communities, they consider the use of fire as a culture method for clearing land for farming. In Central Kalimantan, Indonesia communities considers fire as the most efficient cultural method to clear land for rubber and rice cultivation known as Manusul in their local Dayak language [30]. In Northern Central Highland of Ethiopia, Orthodox churches, considered it is sin and sanctioned for cutting of live trees from church compounds. Thus, they have played a big role of preserving forests rich in diversity of indigenous plants such as Juniperus Procera (Tsihdi Habesha), Olia Africana and Ficus Vasta (Daero) in Ethiopia [31].

Finally, demographic factor include highly in-migration that leads to increased population density in a certain area and has notably influenced land use changes [32, 33]. Various studies argued that increase in population have increased demand for food supply and income resulting to overexploitation of natural resources consequently leading to land use change [10, 30,34]. The linkage between population growth and land use change can also be traced back to the Malthus and Boserup debate (consumption demand approach). This debate has emerged from classic debate of the dynamics of population growth and density inspired by Boserup's critique of Malthusian interpretation [35]. Malthusian theory postulates that the power of population to grow if unchecked is indefinitely greater than the power to produce subsistence for mankind [36]. According to Malthus, growing rural population increases more demand on 
agriculture to feed the ever-increasing population, thereby leading to expansion of agricultural land in marginal land, land fragmentation, decreased productivity and famine, a pathway to poverty and environmental degradation. Moreover, Boserup [33] improved Malthus idea by recognising the role of technology, that population pressure act as catalyst in compelling farmers to implement intensification of agriculture through development and adoption of new technologies. She considered that as population grows, arable land becomes scarce that the spur of scarcity necessitates people to intensify agricultural production. Under this perspective, agricultural change is driven primarily by the changing consumption need of local population due to population growth. Most wetland areas in the globe are experiencing rapidly growing population due to in-migration of people searching for livelihood opportunities which results into strong economic pressure on wetlands ecosystem. Moreover, the intensive agriculture, aquaculture, construction projects, settlement development and other livelihood activities are among key economic pressures that leads to land use change threatening sustainable growth of wetland ecosystem. [10].

The ecological system comprises of geologic setting, patterns of primary productivity, hydrological processes, and other bio-geophysical factors such as climate and its variation [27]. Climate change and variability seems to be associated with extreme weather events such as drought and floods that affect the hydrological systems of the wetlands, soil and vegetation[37]. However, drought push the community to support their livelihoods by encroaching on wetlands to cultivate, access fuel wood, pasture land, food, housing materials, and/or obtain direct monetary income [4]. For example, in the central regions of Tanzania smallholder farmers rely on wetlands for agriculture which is partly considered as adaptation strategy to the drought [38]. Other studies, argued that rainfall patterns act as an important exogenous driver affecting community decisions in carrying out slash-and-burn practice, which in turn resulted in forest fire hence caused massive deforestation [30].

\section{Methodology}

This review synthesizes the interactions of social and ecological systems that led to wetland conversion and land use change in Kilombero Valley Floodplain (KVFP). In order to explain and analyse the ecological variables (e.g. landscape patterns, climate change, variability, and biodiversity) and socio variables (e.g. socio-economic processes) and their interactions, the system thinking approach [39] was adopted to provide a framework for managing complexity interactions between socio-ecological systems over time, understanding of causal feedback structure embedded in these complex systems in the study area.

In order to gather information, extensive literature reviews were explored. Therefore, both published and unpublished papers, reports, wetland related government policies and other secondary literatures relating to socio systems, ecological systems and interactions model for socioecological system that led to wetland conversion and land use change were explored. In addition, research theses, information from Ministry of Natural Resources of Tanzania and National Bureau of Statistics were also consulted. The criteria for inclusion were based on relevance of the literature that reflects the socio-ecological factors for the wetland conversion and land use change.

\section{Presentation of Analysis, Findings and Discussion}

This section explains the social drivers (human activities) and ecological drivers (natural events) that led to wetland conversion and land use change in Kilombero Valley Floodplain (KVFP) based on the reviewed studies and researches.

\subsection{Socio Drivers of Land Use Change and Wetland Conversion}

\subsubsection{Economic Factor}

Several studies have been conducted on economic factor as a driver to land use change and wetland conversion. The economic factor is categorized into three groups; economic structure, market growth, economic variables such as increase in price for the cash crop and timber, and low domestic costs for land, labour, fuel and timber [11]. Market growth of commercial products like timber, cash crops driven by increase in national and international demands reported to cause land use change. In various ways market growth have influenced people to increase production by creating more new land for agricultural production, thus result into land use change and wetland conversion. For instance, it was revealed by Geist and Lambin [11] that increase in price for the cash crop and low domestic costs for land, labor, fuel and timber has influenced land use change in tropical forests.

In Kilombero valley floodplain, market growth and demand for timber products and cash crops such as rice and sugarcane has accelerated land use change and wetland conversion. For instance increased national and international demands for teak timber have influenced Kilombero Valley Teak Company (KVTC) to clear about 22,891 ha of forest for teak trees plantations for commercial purpose. Other commercial companies that own teak plantations in large scale include Green Resources Ltd, Kilombero Sugar Company Ltd and Ifakara Roman Catholic Church [40]. Moreover, increase in price for crops such as rice, cocoa and sugarcane, have encouraged farmers to intensify production as well as extending area under production [7]. These aspects have substantially influenced the changes in agricultural land use system in the Kilombero floodplain. Moreover, improved infrastructures such as main roads and TAZARA line link KVFP to urban /city centers, enabled farmers to transport their farms products to more central markets where they expect to fetch better prices, encouraging them to increase 
production through agricultural intensification and expansion into the wetland. Also, the Structural Adjustment Programmes (SAPs) were the economic reform programmes implemented by the Tanzanian Government in early 1990's have encouraged the development of the private sector in the economy [41] and also influenced land use change in the Kilombero floodplain. Under this reform the government liberalized the marketing of agricultural inputs leading to abolishment of pan-territorial pricing for fertilizers and complete removal of subsidies influence agricultural intensification in KVFP [42]. Also, these SAPs removed state monopoly on crop marketing, creating opportunity for private sector participation in crop marketing as well as providing an opening to farmers to grow crops of their choice depending on market condition. These aspects have considerably influenced the changes in agricultural land use system in KVFP.

Based on economic point of view, economic structure involves the balance of output, trade, income and employment from all economic sectors, such as agriculture, forestry, mining, industries and banking. These sectors depend on each other with one influencing the other, whereby high industrial demands of raw materials from the agricultural sector can influence high productions of raw materials hence causes high demand of land resources.

\subsubsection{Policy and Institutional Framework Factor}

Policy and institutional framework factor plays an important role in enforcing sustainable use of natural resources. The land use based policies and initiatives that seek to promote economic growth has played a role in influencing land use change through encouraging extensive clearance of forests, grasslands and wetland for investment. The study on Wang Thong watershed in Northern Thailand showed that the watershed has experienced significant land use change due to the change in its agricultural policy promoting rubber production for export markets [43]. Similar observations have recently been reported by Zhang et al. [44] where the Chinese government promoted cotton farming resulting in changes in land use particularly expansion and intensification of cotton farming in the expense of the wetlands of Ebinur Lake Watershed, Western China.

This is also the case in Kilombero valley floodplain, whereby various land use related policies implemented by the Tanzanian government have influence land use change and wetland conversion. For instance the implementation of private investment in the forestry sector encouraged by the Tanzania Forest Policy of 1998 influenced the conversion of Miombo woodlands into teak plantations where by a total of 28,000 ha of Miombo woodlands were allocated with a lease for 99 years to Kilombero Valley Teak Company (KVTC) and by 2014 about 22,891 ha of allocated land was planted with teak for commercial purpose [40]. Moreover, under the Tanzania agricultural policy, there was an initiative by the government known as "Kilimo Kwanza" literally meaning in Swahili lingua franca as "Agriculture First", which aimed to provide agricultural inputs such as agro-chemicals and fertilizers to local farmers in order to transform agriculture in Tanzania through modernization of the sector [45]. This initiative influenced significant land use change, particularly with agricultural intensification and wetland conversion in Kilombero valley floodplain. Also, agriculture policy allowed private investment in the Kilombero wetland and this influenced the opening up of large-scale commercial venture such as Kilombero Plantation Limited (KPL) and Illovo Sugar Company Limited that intensify use of land resources in Kilombero valley floodplain.

Land tenure arrangements and policy failures, caused by corruption and mismanagement in various sectors have influenced the land use change [10]. Insecure land ownership and unclear defined property rights of certain natural resources may result into land use change. For instance, wetland resources have traditionally been treated as a public good and exposed to "open access" pressures, with lack of enforceable property rights and this have allowed unrestricted depletion of the wetland resources [26]. Similarly land acquisition and tenure have influenced different land use changes in Kilombero valley flood plain (KVFP) since most of the land is acquired through inheritance and the majority of local people do not have proper title deed, this encourages them to continue encroaching and exploiting the wetland resources resulting into the land use changes and wetland conversion [46].

\subsubsection{Technological Factor}

Technological factor entails the agro-technological advancement that dominantly drives changes in land use, as technology directly affects farmer's behaviour and decisions pertaining to resources utilization, contributing to agricultural expansion and intensification. Also, technological advancement in wood sector associated with the use of advanced machines such as saw machines for logging have resulted into extensive deforestation. Various studies have shown that, poor technological applications in the wood sector have led to wasteful logging practices contributing to tropical deforestation [13]. In this case therefore, both advanced and poor technologies have impact on land resources.

In Kilombero valley flood plain, the advancement of agro technology such as use of power tillers, oxenisation and tractors have assisted farmers to prepare the extensive agricultural areas consequently lead to agricultural expansion and deforestation [47]. Moreover, the increased use of pesticides, fertilizers and improved seeds mainly rice and maize seeds that are generated by KATRIN and Ilonga Research Centre situated in Kilombero district have influenced agricultural intensification thus threatening sustainability of the Kilombero wetland [46].

\subsubsection{Demographic Factor}

Demographic factors affecting land use change include natural growth, migration, population density, population distribution and life cycle features. Increase in these demographic factors in a certain geographical area has stimulated a wide utilization of land resources including land 
for cultivation and grazing, settlement and use of forest products for fuel wood, building material and medicine purpose [32]. Nguyen et al, [10] revealed that the population growth has increased demand for food and improved income that influenced the clearing of wetland for rice cultivation in Ha Tien Plain and Mekong Delta, Vietnam.

Similarly, KVFP has experienced rapid increase in human population due to natural increase and in-migration of pastoralists and agro pastoralists that imposed utilization pressure to the wetland resources [7]. The average population growth rates for the period of 1978 and 1988 to 2002 showed an increase from $3.4 \%$ to $3.9 \%$, which is relatively higher than the national average which is $2.8 \%$ and population density stood at 22 persons per $\mathrm{km}$ in 2002 [48]. The immigrant pastoralists and agro-pastoralists like Maasai, Sukuma and Barbaigs from Mwanza, Shinyanga, Arusha, and Manyara regions have increased pressure on forest and wetland resources as they expand of cultivation land at the expense of other land use [17]. Also, the increased population in KVFP influenced expansion of settlement, clearing of land for agriculture, intensification of agriculture and overgrazing in the wetland leading to land use change and wetland conversion [47]. In most cases the increase of population goes together with the increase in demand of fuel and other human needs. According to Kilombero District report (2009/2010) about $97.7 \%$ of the households in the district, rely wholly or partly on wood fuels (firewood, charcoal and rice husk) for their energy needs. The district profile also indicated that, the rate of consumption of fuel wood exceeded the rate of natural growth, hence, further exploitation of the forest cover. Charcoal making is the common alternative economic activity for most rural communities; especially in, Lupiro, Malinyi, Mtimbira, Mwaya and Makanga divisions, this leads to deforestation in the KVFP. Further, livestock keeping, agricultural activities, settlement, bushfires, charcoal making, fuel wood collection and tree felling for timber and poles are the main reasons for land use change in KVFP [49].

\subsubsection{Cultural Factor}

Cultural factor is linked to public attitude, values, beliefs, public unconcern, individual/household behaviour towards environment [11], including perception of problems, of alternative uses of land, of external influences on land and its productivity. In most communities slash and burning practice for example is implemented as the farm preparation technique and becoming a cultural tradition, as local communities belief it increases soil fertility in the soil degraded land. For instance, bush burning is a cultural tradition of the local Khmer people and this accelerate land conversion in Ha Tien Plain, Mekong Delta, Vietnam [10]. Moreover, insecure ownership related to uncertainties of land tenure in Africa, have driven the shift from communal to private property thereby influencing people to practice traditional shifting cultivation which consequently cause deforestation.

In Kilombero valley floodplain, fire culture is considered as one of the means of agricultural management and a way to clear land for new maize and cocoa farms in upland. These have cause land conversion especially the conversion of bush land and grassland into agricultural land [45]. Also, the practice of traditional shifting cultivation is prominent culture in KVFP where people open up new farms in the forests with the view that forests lands are fertile and they shift to another place when the productivity of the crops drop [50].

\subsection{Ecological Drivers for Land Use Change and Wetland Conversion}

\subsubsection{Climate Change and Variability Factor}

Climate change and variability refers to change in climate over time and/or variation in the mean state of climate on all temporal and spatial scales beyond that of individual weather events [51]. It is among the major driving factors of land use change processes in various ecosystems that influence environmental degradation at the local, regional and global scale. Wetland ecosystems are particularly sensitive to climate change and variability as its affects hydrology, biogeochemical processes, plant communities and ecosystem function [44]. The temperature change in Ebinur Lake Watershed (ELW), Western China leads to high evaporation affecting the hydrology of the wetlands, although there was high precipitation time to time in ELW, the precipitation could not surpass the higher evaporation rate [44]. Moreover, Shi et al., [52] argued that climate zones of higher temperature are subject to higher evapo-transpiration, which restrict the land suitable for agriculture at higher latitudes that accounts for prevalence of irrigated agriculture into the wetland in Northwest China hence leading to wetland degradation.

In Kilombero valley floodplain, climate variability and extreme events such as prolonged dry spells and drought seasons add stresses on upland farming compelling farmers to expand cultivation into the wetlands [46]. Moreover, variability in rainfall patterns has increased pressure on the wetland especially for livestock grazing [7].

\subsubsection{Geologic Setting Factor}

Geologic setting factor refers to topography and terrain characteristic that influence a particular activities which in one way or the other cause the land change and wetland conversion in an area. The most significant variables for geologic setting considered to influence land use changes are slope grade, soil fertility, elevation and aspect [28]. The land use change relating to extensification processes are conditioned on less favourable environmental circumstances, especially steeper slope grade, higher elevation and less fertile soil while intensive land use change is associated with a lower slope grade and elevation and more fertile soils.

In Kilombero valley floodplain, the land use change in the north of the Kilombero river is largely determined by the topography, as the steep slopes of the Udzungwa mountain range are inappropriate for crop cultivation, thus wetland conversion mainly takes place for crop cultivation in the 
floodplain area reaching further towards the Kilombero river, and partly along the forest fringes [50]. Moreover, this is due to the flat terrain and heavy black alluvial soils coupled with high water holding capacity of Kilombero valley floodplain that support agricultural production in the wetland especially for water loving crops such as rice [49]. Moreover, these soils support natural vegetation and pasture for grazing during dry season hence wetland conversion [46].

\subsection{The Interactions and Feedback of Socio-Ecological Drivers in KVFP}

The currently, understanding the interactions of the socioecological drivers to the recent situation of the land use change is essential. It provides reasonable estimates of the level of impact that local activities have on ecosystems compared to impacts caused by processes on larger scales, such as global environmental change [27]. Nevertheless, it also facilitates the formulation of recommendations for ecosystem conservation while enhancing the local community's livelihoods [10]. Although it important to understand the socio-ecological drivers of land use change, there is complicated situation to the interactions between human and ecosystems across-scale, nonlinear feedbacks, and uncertainty, among other factors [53]. Thus, scholars adopted a more realistic approach to the situation, systems thinking approach.

System thinking is a holistic approach to analysis that focuses on how parts of system are constituted and interrelate and how elements work over time and within the context of larger systems[39]. In systems thinking visualization of interrelationships within a complex system helps to measure not only ecological variables (e.g. landscape patterns, climate change, variability, and biodiversity) but also human variables (e.g. socio-economic processes, social networks, agents, and structures of multilevel governance), that provides a framework for managing change and complexity over time, through the understanding of causal feedback structure embedded in complex systems [54]. Systems analysis focuses on: (i) identifying a problem in a boundary system; (ii) developing a better understanding of the problem by clarifying the cause and effect relationships and the feedbacks between different components in a system; and (iii) building a conceptual model of the system at the root of the problem. There are four methodological steps for the systems thinking approach proposed by Vennix [39] represented in Figure 1.

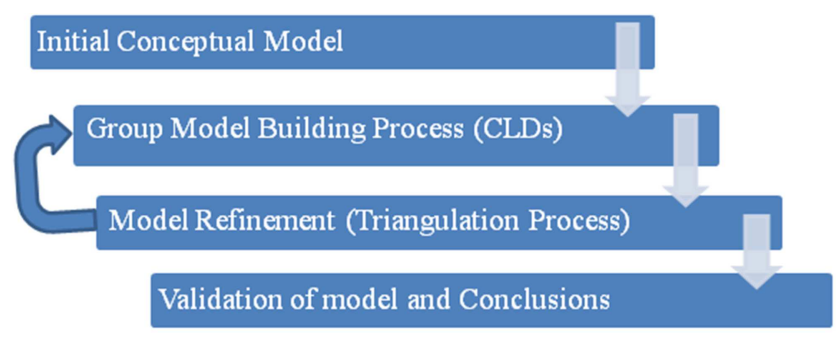

Figure 1. Steps for the System thinking Approach, Adopted from Vennix, [39].

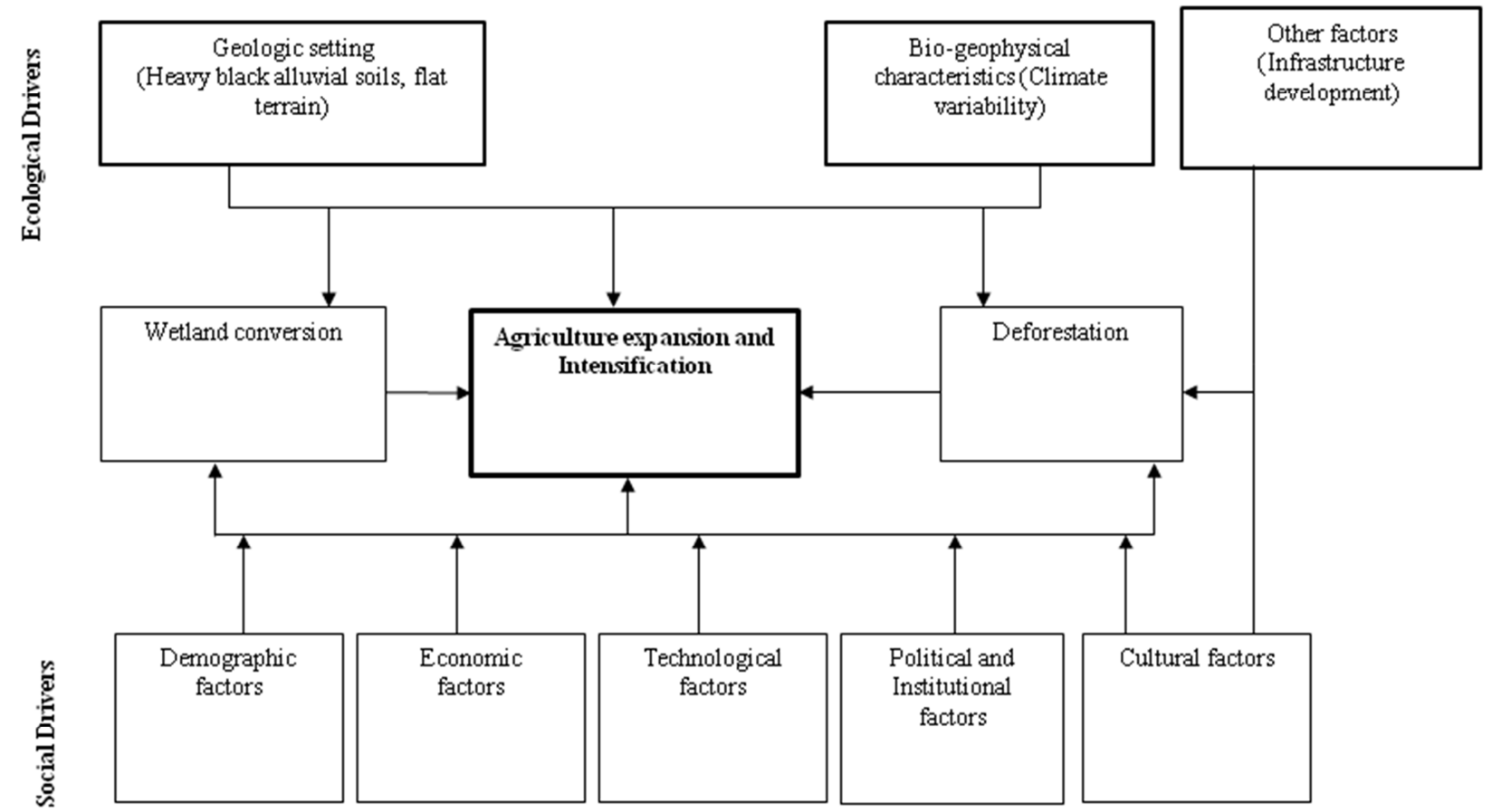

Figure 2. Causative pattern of land use change in Kilombero valley wetland; geological setting and bio-geophysical characteristics have unilaterally impacts land cover change; synergies between ecological causes and underlying (social) driving forces best explain wetland conversion losses. A recurrent sets of mainly demographic, economic, technological, political, and institutional driving forces underpins the socio drivers of wetland conversion, deforestation leading to agriculture expansion and intensification.

The first step involves identifying problems and variables by developing the initial conceptual model focusing on the main factors: welfare, land-based livelihood demand, agrarian land demand, land demand, livelihood activities, 
livelihood production, and land cover. The second step involves the use group model building (GMB) as described by Vennix [39] to identify the major relationships between the elements of the system. This engages the construction of the causal loop diagram (CLD) to develop the causal links between variables, polarities of the link send feedback loops [55] so as to understand stakeholder's motivations in converting land use. The third step entails the model refinement by triangulation process. The triangulation process assists to avoid biased outputs from the GMB, enhance understanding the complex interactions of the system as well as to increase the accuracy and validity of measurements $[54,55]$. The last step is the validation of the model and conclusion.

Based on the reviewed analysis, Kilombero valley floodplain was observed to have four to five socio drivers and two ecological drivers of land use changes and wetland conversion (Figure 2).

A frequent pattern of causal interaction stems from market growth and demand for timber products and cash crops such as rice and sugarcane that associated with the improved road and railway infrastructure, have lead to deforestation and agricultural expansion, which is mostly driven by economic factors as well as policy and institutional factors. The land use related policies that allow private investment in land resources in KVFP (e.g. National agricultural policy of 1997, Forest Policy of 1998) facilitated the establishment of private agricultural and forestry plantations lead to wetland conversion and deforestation. Moreover, Structural Adjustment Programmes (SAPs) in early 1990's encouraged the development of the private sector in the economy, liberalized the marketing of agricultural and complete removal of subsidies influence agricultural intensification in KVFP [42]. Policy, institutional, and economic factors have predisposed Kilombero floodplain into land use change and wetland conversion.

Another pattern, seen in KVFP, comes from insecure land tenure, resulted from uncertainties in land ownership have drive the shift from communal to private property and underlies many cases in which traditional shifting cultivation that direct caused of deforestation. The advancement of agrotechnological in KVFP, is associated with the use of agricultural inputs, power tillers, oxenisation and tractors, favoured local farmers to prepare the extensive agricultural areas consequently lead to agricultural intensification and expansion.

In-migration of pastoralists and agro-pastoralists, natural population growth drive the expansion of agricultural land and pasture in Kilombero valley floodplain, together with other drivers as they act simultaneously. The expansion of permanently agricultural land for subsistence farming to meet the needs of a growing population is reported to cause encroachment into the wetland area. Perception of problems, alternative uses of land, external influences on land and its productivity determined by public attitude, values and beliefs. The traditional culture of slash and burn practices as a way to clear land for new farm has caused deforestation and agriculture expansion in Kilombero valley floodplain. As slash and burn practices On other hand, ecological drivers that influenced land use change and wetland conversion include flat terrain characteristics and heavy black alluvial soils coupled with high water holding capacity, increased temperature and rainfall variability accompanied with prolonged dry spells.

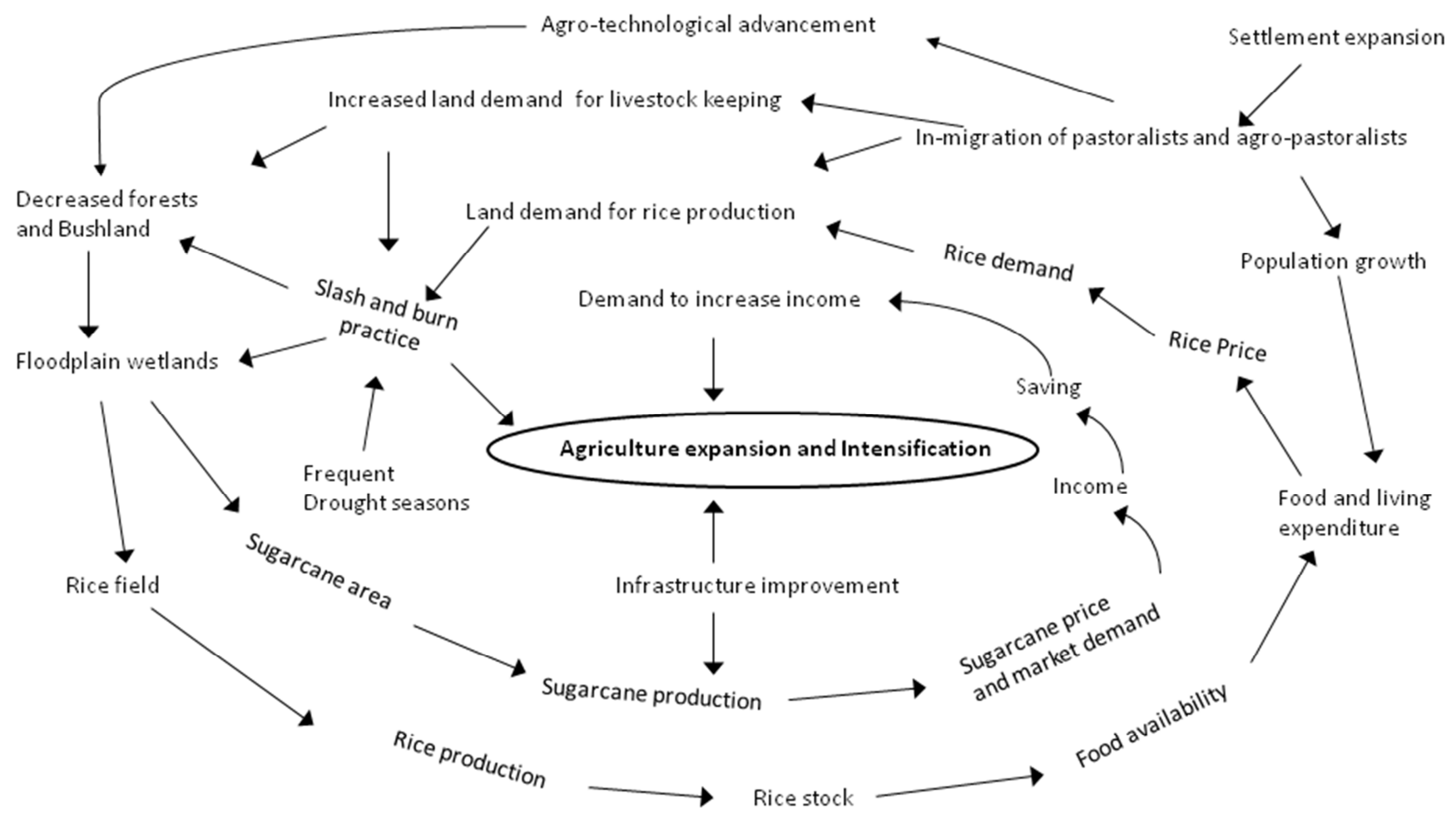

Figure 3. Major feedback and drivers affecting land use change and wetland conversion within the study area. 
Some feedbacks amplify the process of land use change and wetland conversion (Figure 3 ). The main land use change in the area is the agricultural expansion and intensification. The most frequent feedback identified is that from increased demand and prices for the sugarcane, rice and forest products, the creation of new settlements in the area, which work upon economic factors such as Structural Adjustment Programmes (SAPs), investment policies and improvement of the road and railway infrastructures. The in-migration of pastoralists and agro-pastoralists has accelerated deforestation, agricultural expansion and intensification into the wetland in Kilombero valley floodplain. The immigrant agro-pastoralists are said to come with the new farm technology such as the use of the power tiller and their animals to clear and cultivate large area. The increased number of the population in Kilombero floodplain also increased the demand for the land enhancing slash and burn practice that led to deforestation and grassland wetland conversion.

\section{Conclusion}

The dynamic nature of land use in Kilombero valley floodplain and the various drivers that contribute to their dynamism raises important questions for policy makers. Land use changes result from various ecological and human factors within social, economic and political contexts. This review study has examined elements of the social drivers (human activities) and ecological drivers (natural events) that led to land use change and wetland conversion in Kilombero Valley Floodplain (KVFP). The social drivers include increased market demands for cash crops such as rice, sesame and sugarcane coupled with improved road and railway infrastructures, policies that support private investment in the wetland resources, the advancement of agro-technology and increasing human population. On the other hand ecological drivers comprised of climate variability and extreme events such as prolonged dry spells and drought seasons as well as terrain characteristics of flat terrain with heavy black alluvial soils coupled with high water holding capacity. This study will critically improve policy-makers' understanding of socioecological drivers of land-cover change, to influence the development of a better the conservation and management strategies in Kilombero valley floodplain. The conservation measures that will only address the wetland protection without consider the livelihood needs of the local communities will face challenges in implementation. The understanding of socio-ecological drivers and interaction at local scales provides reasonable estimates of the level of impact that local activities have on ecosystems compared to impacts caused by processes on larger scales, such as global environmental change. The study recommends that there should be a call for conservation strategies which are people centred for sustainable wetland management. Moreover, a pragmatic framework for integrated resource management is needed to safeguard people's participation, improvement in the production systems and ensure realization of shared benefits.

\section{References}

[1] Ramsar Convention., (1971). The Ramsar Convention, R. Center, Editor. Rue Mauverney 28, CH 1196, Gland, Switzerland.

[2] Dahl, T. E., (1990). Wetlands losses in the United States s to 1980's, Fish and Wildlife Service, U. S. Department of the Interior: Washington DC, p. 1780.

[3] Ministry of Natural Resources and Tourism, (MNRT), (2007). The National Wetlands Management Strategy. Dar es Salaam, Tanzania.

[4] WWF. (2004). For a living planet. [cited 2018 05/15]; Available from: http://www.panda.org.za/article.php?id=286.

[5] Ramsar Convention, (2008). The Ramsar Convention. Ramsar Cente, in CH 1196, R. M. 28, Gland: Switzerland.

[6] Food and Agriculture Organization (FAO). (1997). Agriculture and climate change: FAO role. Viale delle Terme di Caracall: Italy.

[7] Kangalawe, R. Y. and E. T. Liwenga., (2005). Livelihoods in the wetlands of Kilombero Valley in Tanzania: Opportunities and challenges to integrated water resource management. Physics and Chemistry of the Earth, Parts A/B/C, 30(11), 968975.

[8] Millennium Ecosystem Assessment (MEA). (2005). Ecosystems and Human Well-being: General Synthesis, Island Press, Washington DC.

[9] Foley, J. A., DeFries, R., Asner, G. P., Barford, C., Bonan, G., Carpenter, S. R., Chapin, F. S., Coe, M. T., Daily, G. C., Gibbs, H. K., Helkowski, J. H., Holloway, T., Howard, E. A., Kucharik, C. J., Monfreda, C., Patz, J. A., Prentice, I. C., Ramankutty, N., Snyder, P. K., (2005) Global Consequences of Land Use Change. Science 309, 570-4.

[10] Nguyen, H. H., Dargusch, P., Patrick, M and Ammar A. A., (2017). Land-use change and socio-ecological drivers of wetland conversion in Ha Tien Plain, Mekong Delta, Vietnam. Land Use Policy 64, 101-113.

[11] Geist, H. J. and Lambin, E. F., (2002). Proximate causes and underlying driving forces of tropical deforestation. BioScience 52, 143-150.

[12] Turner II, B. L., Meyer, W. B and Skole, D. L., (1994). Global Land use/ Land-cover Change: towards an Integrated Study. Ambio 23(1), 91-95.

[13] Lambin, E. F., Geist, H. J. and Lepers, E., (2003). Dynamics of Land Use and Land Cover Change in Tropical Regions. Annual Review of Environment and Resources 28, 205-241.

[14] Mwakaje, A. G., (2009). Wetlands, Livelihoods and Sustainability in Tanzania. African Journal of Ecology 47, 179-184.

[15] United Republic of Tanzania, (URT). (2010). Baseline Study of the Kilombero Valley Ramsar Site, Ifakara, Morogoro Tanzania. Department of Zoology and Wildlife Conservation, University of Dar es Salaam, Dar es Salaam. 
[16] Jätzold, R. and Baum, E., (1968). The Kilombero Valley. Weltforum: Munich, Germany.

[17] Gebrekidan, B. H., Heckelei, T and Rasch, S., (2016). The Dynamics of Land-Use Change in Kilombero Valley Floodplain Wetland: An Agent Based Modelling Approach. 2016 [cited 2018; 05/28]. Available from: http://www.tropentag.de/2016/abstracts/links/Gebrekidan_uys 0wdGD.php.

[18] Moser, M., Prentice, C and Frazier, S., (1998). A global overview of wetland loss and degradation. Wetlands International, Ede.

[19] Rubec, C. D. A., (2003). Wetland Stewardship in Canada, in Canadian Wetlands Stewardship. North American Wetlands Conservation Council (Canada), Ottawa, Ontario.

[20] Keddy, P. A., Fraser, L. H., Solomeshch, A. L., Junk, W. J., Campbell, D. R., Arroyo, M. T. K and Alho, C. J. R., (2009). Wet and Wonderful: The World's Largest Wetlands are Conservation Priorities. Bio Science 59(1), 39-51.

[21] Miettinen, J. and Liew, S. C., (2010). Status of Peatland Degradation and Development in Sumatra and Kalimantan. Ambio 39(5), 394-401.

[22] Cowardin, L. M., Carter, V., Golet, F and Laroe, E. T., (1979). Classification of wetlands and deepwater habitats of the United States. Technical Report Archive Image Library, (FWS/OBS-79/31).

[23] Ramsar. (2001). Ramsar Information Paper no 1: What are Wetlands. [cited 2018 05/28]; Available from: http://www.ramsar.org/

[24] Mitsch, W. J., Gosselink, J. G., Söderqvist, T., Mitsch, W. J and Turner, R. K., (2000). The value of wetlands: importance of scale and landscape setting. Ecological Economics 35(1), 25-33.

[25] Dugan, P., (1993). Wetlands in danger: a world conservation atlas. New York Oxford University Press, New York.

[26] Amsalu, T. and Addisu, S. (2014). A review of wetland conservation and management policy in Ethiopia. International Journal of Scientific and Research Publication 4, 9.

[27] Redman, C. L., Grove, J. M and Kuby, L. H., (2004). Integrating Social Science into the Long-Term Ecological Research (LTER) Network: Social Dimensions of Ecological Change and Ecological Dimensions of Social Change. Ecosystems 7(2), 161-171.

[28] Müller, D., (2004). From agricultural expansion to intensification: Rural development and determinants of landuse change in the Central Highlands of Vietnam, in Tropical Ecology Support Programme (TOEB) Report, Deutsche Gesellschaft für: Eschborn.

[29] Rowcroft, P., (2005). Gaining Ground: The Socio-economic Driving Forces Behind Decisions Regarding Land Use and Land Use Change, in Working Paper 16, Vientiane.

[30] Medrilzam, M., Dargusch, P., Herbohn, J and Smith, C., (2014). The socio-ecological drivers of forest degradation in part of the tropical peatlands of Central Kalimantan, Indonesia. Forestry 87, 335-345.

[31] Meshesha, T. W., Tripathi, S. K and Khare, D., (2016).
Analyses of land use and land cover change dynamics using GIS and remote sensing during 1984 and 2015 in the Beressa Watershed Northern Central Highland of Ethiopia. Model. Earth Syst. Environ. 2, 168-180.

[32] Bilsborrow, R. E. and Okoth-Ogendo, H. W. O., (1992). Population-driven changes in land use in developing countries. Ambio 21(1), 37-45.

[33] Boserup, E., (1988). Population Growth as a Stimulant to Agricultural Development. Springer, Berlin Heidelberg. 61-75.

[34] Meyer, W. B. and Turner II, B. L., (1992). Human Population Growth and Global Land Use/Cover Change. Annual Review of Ecology Systematic 23, 39-61.

[35] Boserup, E., (1985). Economic and Demographic Interrelationships in sub-Saharan Africa. Population Development Review. 11(3), 383-397.

[36] Malthus, T. C., (1960). First Essay on Population. Modern Library, New York.

[37] Parry, M. L., Canziani, O. F., Palutikof, J. P., van der Linden, P. J and Hanson, C. E., (2007). IPCC fourth assessment report climate change 2007 - Impacts, adaptation and vulnerability (IPPC WGII AR4). Cambridge University Press: Cambridge, United Kingdom and New York, USA.

[38] Kashaigili, J. J., McCartney, M., Mahoo, H. F., Lankford, B. A., Mbilinyi, B. P., Yawson, D. K and Tumbo, S. D., (2006). Use of a hydrological model for environmental management of the Usangu Wetlands, Tanzania. 2006, IWMI.

[39] Vennix, J. A. M., (1996). Group Model Building: Facilitating Team Learning UsingSystem Dynamics. John Wiley \& Sons, England.

[40] Nindi, S. J., Maliti, H., Bakari, S., Kija, H and Machoke, M., (2014). Conflicts over land and water resources in the Kilombero Valley floodplain, Tanzania. African Study Monograph 50, 173-190.

[41] Mung'Ong'O, C. G., Loiske, V. M., Simon, D., Spengen, W. Van., Dixon, C and Närman, A., (1995). Structural adjustment programmes and peasant responses in Tanzania, 159-183.

[42] Putterman, L., (1995). Economic Reform and Smallholder Agriculture in Tanzania : A Discussion of Recent Market Liberalization, Road Rehabilitation, and Technology Dissemination Efforts. World Development 23 (2), 311326.

[43] Arunyawat, S. and Shrestha, R. P., (2016). Assessing Land Use Change and Its Impact on Ecosystem Services in Northern Thailand. Sustainability 8, 768 .

[44] Zhang, F., Kung, H. and Johnson, V., (2017). Assessment of Land-Cover/Land-Use Change and Landscape Patterns in the Two National Nature Reserves of Ebinur Lake Watershed, Xinjiang, China. Sustainability 9(5), 724.

[45] Wilson, E., McInnes, R., Mbanga, D. P and Ouedraogo, P., (2017). Ramsar Advisory Mission Report; Ramsar Site No. 1173. Kilombero Valley, United Republic of Tanzania, Dar es Salaam, Tanzania.

[46] Msofe, N. K., Lyimo, J, and Saria, J., (2014). Anthropogenical Drivers on Land Use/Cover Change and their Implications to Rural Livelihood in Kilombero Wetlands, Tanzania, Hurial Journal. 
[47] Mombo, F. M., Speelman, S., Van Huylenbroeck, G., Hella, J., Pantaleo, M and Moe, S., (2011). Ratification of the Ramsar convention and sustainable wetlands management: situation analysis of the Kilombero Valley wetlands in Tanzania. Journal of Agricultural Extension and Rural Development 3(9), 153-164.

[48] United Republic of Tanzania, URT. (2012). Population and Housing Census. 2013, Government Printer, Dar es Salaam.

[49] Ntongani, W. A., Munishi, P. K., More, S. R and Kashaigili, J. J., (2014). Local Knowledge on the Influence of land use/cover changes and conservation threats on Avian community in the Kilombero Wetlands, Tanzania. Open Journal of Ecology 4(12), 723.

[50] Leemhuis, C., Thonfeld, Frank., Näschen, K., Steinbach, S., Muro, J., Strauch, A., López, A., Daconto, G., Games, I and Diekkrüger, B., (2017). Sustainability in the Food-WaterEcosystem Nexus: The Role of Land Use and Land Cover Change for Water Resources and Ecosystems in the Kilombero Wetland, Tanzania. Sustainability 9, 1513.

[51] Kumar, P., Martino, D., Smith, P and Al, Et., (2007). Agriculture (Chapter8) in IPCC, 2007: Climate change 2007:
Mitigation of Climate Change. Contribution of Working Group III to the Fourth assessment Report of the Intergovernmental Panel on Climate Change.

[52] Shi, Y. F., Jiang, N and Yao, L., (2003). Discussion on the present climate change from WARM-DRY to WARM-WET in northwest CHINA. Quat. Sci 23, 152-164.

[53] Liu, J., Dietz, T, Carpenter, S. R., Folke, C., Alberti, M., Redman, C. L., Schneider, S. H., Ostrom, E., Pell, A. N and Lubchenco, J., (2007). Coupled Human and Natural Systems. Ambio 36(8), 639-649.

[54] Schultz, L., C. Folke, and P. Olsson., (2007). Enhancing ecosystem management throughsocial-ecological inventories: lessons from Kristianstads Vattenrike, Sweden. Environ. Conserv, 140-152.

[55] Schaffernicht, M., (2010). Causal loop diagrams between structure and behaviour: acritical analysis of the relationship between polarity, behaviour and events. Syst. Res. Behav. Sci, 653-666. 